\title{
The Value of Financial INTERMEDIARIES: EMPIRICAL EVIDENCE FROM SYNDICATEd LOANS TO EMERGING MARKET BORROWERS
}

\author{
by \\ Greg Nini \\ Federal Reserve Board\# \\ Version: 9/29/2004
}

\begin{abstract}
Empirical estimates of the benefit of financial intermediation are constructed by examining the role played by local banks in facilitating syndicated loans to borrowers in emerging market countries. A ssuming that local banks possess a superior monitoring ability, the market is ideal for studying the value of intermediation since cross-border lending into emerging markets is plagued by particularly high information and agency costs and the supply of local bank capital is in limited short run supply. Using variation in the propensity of local banks to participate in foreign arranged syndicates, there are two economically important results. First, local banks are much more likely to participate in unconditionally riskier loans. Second, after controlling for borrower characteristics, loan characteristics, and the endogeneity of the local bank lending decision, loans with local bank participation have spreads that are 10 percent lower (29 basis points) than otherwise similar loans. Combined, the results support the conclusion that local banks, a particularly special type of financial intermediary, provide value by considerably reducing financing costs, especially for riskier borrowers.
\end{abstract}

JEL Classification: G20, G21, G15.

Keywords: financial intermediation, bank loans, emerging market finance.

\footnotetext{
\# The ideas expressed here do not represent the opinions of the Board of Governors of the Federal Reserve System or its staff. This work has benefited from discussions with M ark Carey, Sally Davies, Dick Freeman, and David Smith. Address correspondence to Greg Nini, Board of Governors, M ailstop 19, 20 th and C Streets NW, W ashington DC 20551. Telephone: 202-452-2626. Email: gregory.p.nini@frb.gov.
} 


\section{Introduction}

In the years since the work of Diamond (1984) and James (1987), it has become conventional wisdom that financial intermediaries (hereafter "banks") act as delegated monitors and that their activity adds value to firms. The understanding is that banks perform credit screening and monitoring that is not done by investors in publicly issued bonds or equity. More recently, the literature on "finance-and-growth" has established a link between banking sector size and the economic progress of nations, providing empirical support that banks' unique value is important enough to affect macroeconomic outcomes (Levine, Loayza, and Beck 2000 provides a review).

The research reported here contributes to these literatures by quantifying part of the benefit transferred to borrowers in emerging markets by locally domiciled banks, who are likely acting as a delegated monitor à la Diamond. Syndicated loans to borrow ers in emerging markets are supplied by a combination of foreign developed country lenders and local banks, providing the empirical opportunity to examine the role played by local banks. Emerging market financings are a useful vehicle for identifying the role of banks for two reasons. First, emerging market borrowers are typically presumed to be more opaque than developed country borrowers and legal protections for investor are often weaker (La Porta et al 1998). M oreover, local banks are presumed to be better informed about local borrowers and more able to navigate the local legal system (Berger, Klapper, and Udell 2001). Second, limited short run lending capacity of the local banking system prevents banks from participating in all syndicated loans, providing a sample of firms who borrow entirely from foreign banks to serve as a comparison group for statistical testing.

A rich, loan-level data set on loan syndications is used to compare loans with and without a local bank participating in the syndicate. Assuming that local banks face capital or funding constraints that prevent them from participating in all local firm loans, the empirical tests are of a joint hypothesis: local emerging market banks are better monitors than foreign banks; and monitoring matters, benefiting borrowers through a reduced cost of capital. Empirical results support the hypothesis: Local banks are much more likely to participate in loans to riskier firms, where the benefits of monitoring are larger; and interest rate spreads paid by borrowers are 10 percent ( 29 basis points) smaller on average when a local bank participates in the syndicate, a large effect despite local banks typically funding only a small share of the loan. These results are from tests that control for borrower characteristics, loan characteristics, and the endogeneity of syndicate participation decisions by local banks.

This new evidence makes three contributions to the literature. First, much of the existing empirical evidence that bank monitoring has value is from the behavior of equity returns. On average, a firm's equityholders react positively to the announcement of a bank loan but negatively to issuance of bonds or common equity (Hadlock and James 2002). This suggests 
that bank involvement, or characteristics unique to loan contracts, offer positive externalities not conveyed by other forms of finance. M oreover, excess equity returns are largest for loans to small firms (Slovin, Sushka and Poloncheck 1993) and relatively opaque firms (Best and Zhang 1993), suggesting that bank monitoring is most valuable when adverse selection and/or moral hazard are most severe. The results here add significantly to the case for valuable bank monitoring because they are the first based on loan prices, and they confirm that costs of Ioan finance are reduced by valuable monitoring.

Second, the evidence suggests that mechanisms supporting bank monitoring activity are more complex than has been presumed to date. Loan syndicates deviate from the canonical Diamond model in that several lenders jointly advance funds to a borrower under the same loan contract, potentially raising the need for duplication of monitoring effort. The lead arranging bank in the syndicate has been presumed to do all the monitoring, to be diligent in order to maintain its reputation, and to fund a larger share of the loan the more challenging the monitoring task (Dennis and Mullineaux 2000 present some evidence supporting this view). The evidence here suggests that non-lead banks funding only a small portion of the loan can perform a monitoring function; and the size of the spread impact suggests that the monitoring benefit provides significant externalities to other lenders in the syndicate.

Third, the evidence offers fresh support for an important role for banks in economic growth. Since financial development is often measured as the size of the local banking sector relative to the size of the economy, prior research results suggest that domestic banks have no close substitute. ${ }^{1}$ Here, the role served by local banks in securing financing for riskier borrowers and reducing loan spreads is shown to be large enough to plausibly lead to a substantial increase in economic activity. Recently, financial development has further been linked to larger average firm size (Beck, Demirgic-Kunt, and Maksimovic, 2003) and longer average debt maturity (Demirguc-Kunt and Maksimovic, 1999), suggesting that the value of banks stems from their superior screening and/or monitoring abilities that reduce information and agency costs. The empirical results here support this conclusion, since the evidence indicates that riskier borrowers benefit most from local banks. For example, local bank participation rates and loan spread reductions are larger during periods of high country credit risk, such as Latin America during 2002 and in Eastern Europe during 1999. Monitoring services are likely to be most beneficial during such periods. These results suggests that the positive externalities extending to other syndicate members likely reflect local banks' superior screening and/or monitoring capabilities.

\footnotetext{
${ }^{1}$ In this paper, the definition of a local bank excludes the subsidiaries of foreign parent banks, which would be included in the country level aggregate measure of financial development. H owever, Berger, Klapper, and U dell (2001) show that foreign owned institutions are less likely to lend to opaque small business, suggesting a competitive disadvantage.
} 
The remainder of the paper is organized as follows. The next section provides a discussion of syndicated lending to emerging market borrowers, highlighting features of the syndication process that relevant for the empirical predictions. Section 3 introduces the empirical set-up, an endogenous switching regression model that endogenizes the local bank funding decision. Section 4 describes the construction of the loan sample and explanatory variables, including the instruments for local bank participation that are used to identify the model. Section 5 discusses of the results, and the final section summarizes section draws some conclusions.

\section{Syndicated Lending to Emerging $M$ arket Borrowers}

Syndicated loans involve a collection of banks jointly extending a loan to a particular borrower. Typically, a single loan contract is negotiated by a small number of arranging banks, and a larger number of participant banks join in funding the loan. ${ }^{2}$ In addition to fees shared among the lenders, all lenders providing funds are entitled to receive the contractually determined loan spread, set as a floating rate over a common reference rate such as LIBOR. In general, participants in syndicated loans to emerging markets are motivated by the high spreads offered on the assets as well as the opportunity to diversify their loan portfolios.

\subsection{The Syndication Process}

The life-cycle of a syndicated loan consists of three distinct phases. During the pre-mandate phase, borrowers typically initiate discussions with potential arranging banks and solicit competitive offers to arrange the loan. Individual banks or groups of banks then make proposals to the borrower, indicating their initial preference for various loan terms (e.g. final maturity and covenants) and pricing. From the proposals, the borrower chooses an arranging bank or group of banks and negotiates a more complete loan contract and tentative pricing structure. During the post-mandate phase, the arranger(s) commences with the actual syndication process, which includes drafting an initial version of the loan contract, preparing an information package to send to potential participants, and formally inviting participant banks to join the syndicate. Finally, during the post-signing phase, the loan becomes operational and both borrowers and lenders are bound by the stipulations of the loan contract. Further discussion of the post-mandate phase highlights how participating banks can influence the structure and pricing of a syndicated loan.

The post-mandate phase begins with the borrower and arranger collectively organizing an information memorandum, which documents the principal credit issues associated with

\footnotetext{
${ }^{2}$ Non-bank financial institutions (including investment banks, insurance companies, hedge funds, and special purpose financing vehicles) also participate in loan syndications. However, the term 'bank' will often refer to any member of the syndicate.
} 
the loan. The purpose of the information memorandum is to inform potential participants about the credit quality of the borrower and specific terms and conditions associated with the particular loan. M arket participants suggest that the exact nature of this document varies across both borrowers and potential participants. Less well known borrowers and borrowers of poorer credit quality require a more extensive release of information. Similarly, potential lenders that are less familiar with the borrower or the borrower's industry and location often demand more disclosure.

The initial set of targeted participants is largely determined by the arranging bank(s), possibly with some input from the borrower. M arket participants suggest that several initial criteria are used to identify potential interest, including banks with previous working relationships with the arranger(s), banks who have participated in loans to borrowers from a similar region or industry, and banks with previous experience with the particular borrower. If this set of banks appears too small, the arranger(s) will cast a wider net by more broadly advertising the deal. Here is where the arranger's experience and reputation are particularly important.

After distributing the information memorandum, the borrower and arranging bank(s) often launch a 'roadshow', where they have the opportunity to sell the transaction to interested participants. The arranger and borrower jointly present information similar to that in the information memorandum but al so permit participants to ask questions and personally meet the individuals associated with the transaction. Market participants again suggest that this process is particularly important for less well known borrowers, such as first-time borrowers in the market.

The information memorandum and roadshow suggest that information asymmetries are an important source of friction in the lending process. Obviously, information asymmetries are loan specific, varying with the borrower's country and industry, the borrower's history, and other borrower specific characteristics. Additionally, the post-mandate phase suggests that information asymmetries are primarily mitigated through increased disclosure and selective choice of potential participants who are likely to be at the least information disadvantage.

After the roadshow, the arranging bank(s) makes formal invitations to potential participants. W hile the borrower may have some input in this step, the arranger is generally free to determine the set of potential participants. The number and choice of participants is influenced by the arranger's opinion of the market's potential supply of funds. Arrangers want to avoid over-subscription, since that can leave participants with smaller amounts than they were anticipating. They also want to avoid under-subscription, since the remedies can leave an impression of failure that will hurt future business. The result is that arrangers tend to target participants with the "largest appetite" for the loan and make invitations to banks willing to supply the most funds given the structure of the loan. 
The final step is for the arranging bank(s) to determine the allocation given to each participant, with the arranger adjusting participant commitments to match the borrower's desired loan size. In the case of over-subscription, the borrower may choose a larger loan or the arranger can scale back allocations. If the syndication is under-subscribed, the arranger must either make up the difference or change loan terms and re-market the deal. W ith fully underwritten loans, the arranger(s) must make up the difference under the existing loan terms. M ore common, how ever, is that the syndication is done on a best efforts basis, so the arranger(s) can change the terms of the loan (e.g. increase pricing or shorten maturity) to make it more attractive to participants. Some portion of the post-mandate phase is then repeated to attract larger commitments or new participants.

The various steps of the syndication process highlight that problems of asymmetric information present a considerable concern related to the provision of the loan. M oreover, information acquisition is the primary means for addressing the problem, and the arranging banks work to minimize the cost of this process.

\subsection{Syndicated Lending into Emerging $M$ arkets}

Syndicated loans represent an important source of external finance to emerging markets. Table 1 compares three components of the flow of private market financing into emerging markets: equity, bond, and syndicated loan financing. In general, Ioan syndications provide financing comparable to bond markets and much larger than equity markets. While importance varies across regions and over time, syndicated loans have served an important role in financing emerging market borrowers during this period.

Syndicated loans are most often arranged by banks from developed countries who may or may not have a local presence in the borrower's country. Loan arrangers tend to be large, internationally active banks who have the networking ability to place the loan with a wide range of participants. Table 2 presents syndicated loan market shares in Latin America and Eastern Europe for lenders from several regions around the world. The data suggest that W estern European lenders have been significant lenders into both regions, while North A merican lenders have done significant lending into Latin A merica.

The market shares of banks from Latin America and Eastern Europe provide circumstantial support for two important assumptions. First, despite being a natural source of funds to local borrowers, banks from Latin America and Eastern Europe provide only 6 percent of the funding to their local borrowers. While not conclusive, the small share suggests that capital constraints are severe enough to keep local banks from controlling the market. Second, banks from Latin America and Eastern Europe lend only to their local borrowers and have not participated in any loans to borrowers outside their local region. ${ }^{3}$

\footnotetext{
${ }^{3}$ Emerging market banks have participated across country borders but not across regions.
} 
This intimates that emerging market banks have an advantage lending to their local borrowers that does not transfer to foreign borrowers. ${ }^{4}$ Combined, the market share statistics are consistent with the assumption that local banks have limited means to offer their unique abilities to all borrowers.

\section{Empirical Set-Up}

Participation decisions of local banks are presumably based on the benefits and costs of inclusion versus the alternative of using only foreign banks. Treating the participation decision as endogenous, loan spreads are modeled with an endogenous switching regression model first analyzed in Maddala and Nelson (1975), ${ }^{5}$ The model consists of two spread equations and an equation that determines which syndicate structure is actually observed. Correlation between the error terms in the equations controls for the endogeneity of the participation decision, since both participation and loan spreads are likely related to variables not observed in the data.

Empirically, letting $I$ be a 0-1 variable that indicates the presence of a local bank and $S_{L}$ and $S_{N}$ be loan spreads with and without local participation, respectively, the model is given by the following equations:

$$
\begin{aligned}
& \ln S_{L}=\beta_{L}{ }^{\prime} X+\mu_{L} \quad \text { if } I=1 \\
& \ln S_{N}=\beta_{N}{ }^{\prime} X+\mu_{N} \quad \text { if } I=0 \\
& I^{+}=\beta_{I}{ }^{\prime} Z-\mu_{I} \\
& I=\left\{\begin{array}{l}
1 \text { if } I^{+}>0 \\
0 \text { otherwise }
\end{array},\right.
\end{aligned}
$$

where $X$ is a set of exogenous variables affecting loan spreads, $Z$ is a set of exogenous variables affecting the probability of local participation, and $\mu_{L}, \mu_{N}$, and $\mu_{I}$ are error terms capturing the effect of unobservable risk factors. The vector of variables $Z$ includes all the variables in $X$, plus additional variables that assist with model identification.

Correlation between the random variables $\mu_{I}$ and $\mu_{L}, \mu_{N}$ truncates the sample of observed loan spreads, since $E\left(\mu_{L} \mid X, I=1\right) \neq 0$ and $E\left(\mu_{N} \mid X, I=0\right) \neq 0$. Intuitively, the inclusion of a local bank reveal sinformation about unobservable characteristics that may also influence the resulting loan spread. OLS estimates of $\beta_{L}$ and $\beta_{N}$ from (1) are inconsistent.

\footnotetext{
${ }^{4}$ Carey and Nini (2004) document a similar 'home bias' for borrowers from developed countries.

${ }^{5}$ M iller and Puthenpurackal (2002) compare spreads on Y ankee bonds and Eurodollar bonds using a switching regression model that permits issuance choice to be endogenous.
} 
However, assuming that the error terms are independently and identically distributed across observations as multivariate normal with zero mean vector and covariance matrix

$$
\operatorname{cov}\left(\mu_{L}, \mu_{N}, \mu_{I}\right)=\left[\begin{array}{ccc}
\sigma_{L}^{2} & \sigma_{L N} & \sigma_{L I} \\
& \sigma_{N}^{2} & \sigma_{N I} \\
& & 1
\end{array}\right],
$$

the model is estimated by full information maximum likelihood.

Since only one spread per loan is observed, counterfactual loan spreads must be constructed with the estimated model parameters. The counterfactual loan spreads are then used to assess the impact of local lender participation. The error terms in (1) are conditionally normally distributed:

$$
\begin{aligned}
& \left(\mu_{N} \mid X, I=1\right) \sim \mathrm{N}\left[-\sigma_{N I} \lambda_{L}, \sigma_{N}^{2}-\sigma_{N I}^{2} \lambda_{L}\left(\beta_{I}{ }^{\prime} Z+\lambda_{L}\right)\right] \\
& \left(\mu_{L} \mid X, I=0\right) \sim \mathrm{N}\left[\sigma_{L I} \lambda_{N}, \sigma_{L}^{2}-\sigma_{L I}^{2} \lambda_{N}\left(\beta_{I}^{\prime} Z+\lambda_{N}\right)\right] \\
& \text { where } \lambda_{L}=\frac{\phi\left(\beta_{I}^{\prime} Z\right)}{\Phi\left(\beta_{I}^{\prime} Z\right)}, \lambda_{N}=\frac{\phi\left(\beta_{I}^{\prime} Z\right)}{1-\Phi\left(\beta_{I}^{\prime} Z\right)} .
\end{aligned}
$$

For loans with local participation, the counterfactual of interest is the expected loan spread without local participation, conditional on the fact that the loan did have local participation, $\mathrm{E}\left(S_{N} \mid X, I=1\right)$. The impact of local participation is then given by the difference between the actual loan spread $S_{L}$ and this counterfactual. Using (1) and the properties of the lognormal distribution, the counterfactual is given by

$$
\mathrm{E}\left(S_{N} \mid X, I=1\right)=\exp \left(\beta_{N}{ }^{\prime} X+\mathrm{E}\left(\mu_{N} \mid i=1\right)+.5 \operatorname{Var}\left(\mu_{N} \mid i=1\right)\right) .
$$

Substituting empirical estimates into (2) and (3) yields the estimates used to construct the counterfactual and the estimated local lender impact. The counterfactual is constructed for each sample loan, resulting in a sample of loan spreads and estimated counterfactuals. Various statistics from this sample are used to make inferences about the impact that local borrow ers have on borrowing costs.

\section{Sample Construction and Identification}

\subsection{Loan Data Generation}

Loanware is a dataset compiled by a division of Dealogic, a joint venture by Computasoft Ltd. and Euromoney Institutional Investor PIc. Dealogic compiles new issue information on global syndicated loans, collecting borrower information, syndicate composition, and various 
details of each loan. The original sample consists of all loan tranches in the Loanware database where the borrower is from a country in Eastern Europe or Latin America. Restricting the sample to loans signed between the beginning of 1995 and the end of 2002, the May 2003 release yields 3,969 unique loan tranches. ${ }^{6}$ In order to create a homogeneous sample of syndicated loans to non-sovereign entities, several categories of loans are removed from this set: first, tranches identified as amendments to existing loans and loans remaining uncommitted as of the release date; second, loans identified as private placements and bilateral loans between a borrower and a single lender; third, loans to borrowers identified as government entities and project finance companies; fourth, loans not made in U.S. dollars or Euros (including legacy currencies) and loans not priced over LIBOR. These restrictions reduce the sample to 3,095 tranches. Next, tranches without complete syndicate information (including all arranging and participant banks, along with amounts provided), pricing information, and maturity are dropped. These restrictions reduce the sample to 1,384 loan tranches. ${ }^{7}$ Finally, the sample is restricted to countries with at least 20 tranches meeting the above criteria. This final restriction leaves a final sample of 1,143 loan tranches to borrowers in 13 countries.

Table 3 provides the list of countries included in the sample along with the number of tranches from each country. In Latin America, the sample is dominated by borrowers from Argentina, Brazil, Chile, and Mexico. The distribution is more even in Eastern Europe, except that Russian borrow ers represent roughly 40 percent of the sample.

For each lender in the syndicate, Loanware provides both the lender's country of domicile as well as information about any parent organization, including country of domicile. For the purpose of this study, a local lender is defined as a bank domiciled in the same country as the borrower that does not have a foreign parent. Since considerable merger and acquisition activity occurred during the sample period, the Bankers Almanac W orld Ranking is used to verify the nationality of each bank's head office. ${ }^{8}$

Using this definition of a local lender, foreign banks with subsidiaries in the borrower's country are not considered as local and are grouped with foreign banks that do not have a local subsidiary. This definition of a local bank is potentially restrictive, but it isolates banks

\footnotetext{
${ }^{6}$ On occasion, a single borrower will enter into more than one loan tranche organized by the same arranger(s) and commencing on the same day. Rather than aggregate multiple tranches into a single loan "deal", each tranche is treated as a separate observation. Results are robust to the random exclusion of all except one tranche in a deal.

7 The significant exclusion predominately reflects loans without pricing information. The incidence of missing information is slightly higher than that for loans to borrowers in developed countries. The excluded tranches tend to be smaller and have fewer lenders but otherwise appear similar.

${ }^{8}$ The Bankers A Imanac data is hand collected from printed sources, which is the primary reason that the sample is restricted to Latin America and Eastern Europe. Among emerging market regions, developing Asia has the most advanced syndicated loan market but has significantly more banks to check ownership.
} 
most likely to have an information and/or monitoring advantage as well as banks subject to capacity constraints. Foreign banks with a local subsidiary have a foreign source of capital at their disposal, making it empirically much harder to identify exogenous factors that affect the likelihood of inclusion in the syndicate. Identifying differences between foreign banks with and without a local presence is left for future research.

Table 3 also provides information about the lenders participating in each country. The second and third columns report the total number of unique local and non-local lenders that have participated in at least one sample loan. Notice that the number of local banks varies significantly across countries, with Brazil having 15 local banks and the Czech Republic having only 2 local banks. In the multivariate results presented below, the number of local banks is used as a variable to control for differences in the likelihood of local participation. Similarly, columns 5 and 6 report the aggregate frequency with which local and non-local banks participated in sample loans. W hile non-local banks are present in every syndicate, local banks participate in roughly 27 percent of the loans across the whole sample. Again, there is significant heterogeneity across countries. Finally, columns 7 and 8 report the average share of the loan provided by local and non-local banks, conditional on local participation. M ost importantly, when local banks do participate, they provide a modest but non-trivial share of the loan, averaging 13 percent of the total in Eastern Europe and 16 percent in Latin America.

\subsection{Local Bank Inclusion Variables}

One cost of including a local bank is related to the cost of capital that the local bank must use to support the loan. Local bank capital is scarce and in inelastic supply in the short-run, which creates both a direct cost and an opportunity cost since capital committed to a syndicated loan becomes unavailable for alternative uses. Empirically identifying variables related to capital costs is difficult, and Table 3 suggests that they likely vary by country. Moreover, capital costs likely vary over time as conditions in local savings and investment markets change.

Two variables are used to capture variation in capital costs. First, NUM BNK is the natural logarithm of the number of local banks that have participated in a syndicate in the borrower's country. This variable represents the total number of local banks available to arranging banks when selecting participants. W hile this variable is potentially endogenous, comparison of the values with the Bankers A Imanac W orld Ranking suggests that nearly all large local banks have participated in at least one syndicated loan. So this variable really captures the total count of potential local banks.

Second, LOCALLIQ is the ratio of the liquid liabilities of banks to GDP in the borrower's country, constructed annually from the IM F's International Financial Statistics. This variable is available historically in the World Bank's Financial Development Database and is often 
used as a measure of financial development. Here, variation across countries and over time is used to capture variation in financing capabilities. Liquid liabilities are comprised primarily of time, savings, and foreign currency deposits of resident sectors other than the central government. This represents the primary source of funding for local banks and is likely to be highly correlated with the cost of local bank capital. Esty (2003) uses this country level variation in this variable and finds that domestic banks supply a larger fraction of funds in project finance loans when the domestic banking market is deep.

\subsection{Credit Risk Variables}

Institutional Investor country credit ratings control for variation in credit risk across countries. This variable, labeled IICREDIT, is taken from the most recent issue of Institutional Investor magazine prior to the signing of the loan. The measure is based on a biannual survey of approximately 100 international bankers that results in a score between 0 and 100, with higher values representing better risk. The variable is measured at the country level and only varies at a twice per year frequency. Both a linear term and a squared term IICREDITSQ are included to permit non-linear effects. Further since credit risk varies with macroeconomic business cycles, IICREDIT and IICREDITSQ are interacted with year dummy variables to permit the marginal effects to vary over time. This interaction helps remove some of the ordinal nature that is likely part of the ratings. The 8 years of data yields 16 total variables to capture country and year level variation in credit risk. Esty (2003) finds this variable is significantly related to spreads on project finance loans.

Since NUMBNK and LOCALLIQ capture differences in local bank inclusion costs and IICREDIT-year variables measure credit risk, empirical identification of the local bank effect results primarily from comparing loans made in country-years of similar credit risk with different numbers of local banks and/or liquid liabilities. The implicit assumption is that NUM BNK and LOCALLIQ are correlated with the probability of local bank participation but conditionally uncorrelated with credit risk so as to not affect loan spreads. The data support this assumption.

Several other explanatory variables related to the loan and the borrower are used to provide additional controls for observable differences in credit risk. Only a small percentage of borrowers have outstanding debt that is rated by a rating agency (Standard and Poor's or Moody's), so the dummy variable UNRATED is set to one to simply indicate the lack of an agency rating. Borrowers without a rating are likely to be of worse credit quality, less transparent, and carry higher spreads.

Three dummy variables are related to the type of borrower. First, FINANCIAL indicates that the borrowing firm is a financial intermediary. Financials are known to have unique credit risk related to the nature of their liabilities (which are often deposits) and explicit or implicit public support. Second, PUBLIC is a dummy variable that indicates the borrower is 
at least partially owned and controlled by the government. Similar to a financial firm, a public firm may receive explicit or implicit financial support that makes it a better credit risk. Finally, LOCALFIRM is an indicator that the firm is locally owned and controlled, as opposed to an affiliate of a foreign firm. Most borrowers are not subsidiaries of foreign parents, who likely present a unique credit risk due to the existence of a parent organization based in another country. Borrower industry dummy variables are included as further controls for credit risk. Telecommunications, real estate, and energy-related firms are responsible for a large portion of total borrowing, measured by the count and quantity of total loans, in emerging markets during the period.

Several dummy variables are related to the type and purpose of the loan. The dummy variable TYPE_REV indicates that the tranche is a revolving credit facility, with the alternative being a funded term loan. Under a revolving facility, many of the proceeds available to the borrower are not drawn, exposing lenders to less credit risk and typically resulting in smaller spreads. PURP_CHGCTRL indicates that the loan is funding an event that changes significant control of assets, such as a merger or acquisition. PURP_CAPSTR indicates that the loan funds are being used to manage the borrower's capital structure, for example by refinancing existing debt. Relative to a loan for working capital, the excluded category, such loans are typically considered riskier and carry higher spreads. These variables help control for differences in credit quality across sample loans and may also be related to the propensity for local banks to fund the loan.

Several contract specific loan terms are used to provide further controls for credit risk: the size of the loan, the maturity of the loan, and an indicator of the presence of collateral. Since all of these variables are endogenous, estimated coefficients are likely biased and not directly interpretable. However, they do provide a control for the credit risk associated with the borrower. M oreover, discrete variables are created to minimize the endogeneity problem, using endpoints near sample quartile values to create dummy variables. SIZE50100 indicates a loan between $\$ 50 \mathrm{M}$ and $\$ 100 \mathrm{M}$; SIZE100150 indicates a loan between \$100M and \$150M; SIZE150250 indicates a loan between \$150M and \$250M; and SIZE250p indicates a loan larger than $\$ 250 \mathrm{M}$. The largest category includes roughly the top 10 percent of loans by size. MAT1836 indicates a maturity between 18 months and 3 years; MAT3660 indicates a loan between 3 years and 5 years; and MAT60P indicates a loan longer than 5 years. Finally, SECURED indicates a loan that is specifically collateralized. Reported results are robust to the specific form of the maturity variable and the exclusion of SECURED. Results are rather sensitive to the specific form of the size variable, but the qualitative conclusions remain. The likelihood of local bank participation appears highly non-linear in the size of the loan, likely due to the fact that loan size reflects both the nature of the underlying project and the credit risk of the borrower. Larger loans are typically granted to less risky borrowers, yet larger 
loans require more capital that can strain the capacity of foreign banks. ${ }^{9}$ These confounding effects are difficult to separate.

Finally, the number of members in the syndicate is used to provide an additional control for various factors that influence both the credit risk of the borrower and the likelihood that a local bank is included in the loan. Carey and Nini (2004) show that syndicated loan spreads are positively correlated with the number of lenders in the syndicate, possibly due to reduced access to ancillary business from developing a relationship with the borrower. Alternatively, the number of syndicate members may be a proxy for the credit risk of the borrower, since lenders manage exposure to riskier borrowers. A discrete version of lender number is created as follows. NBA NK46 indicates a loan with at least 4 lenders but no more than 6 lenders; NBANK713 indicates a loan with at least 7 lenders but no more than 13 lenders; NBANK14P indicates a loan with at least 14 lenders; and the excluded category is loans with less than 4 lenders. These categories are roughly the sample quartiles, but results are robust to the exact specification of this variable.

\section{Empirical Results}

The empirical model (1) is estimated by maximum likelihood, using the Newton-Raphson algorithm with numerical derivatives. The estimated variance is given by the inverse of the information matrix, computed numerically using the final Hessian matrix. All hypothesis tests use simple W ald statistics, which use the asymptotic standard errors and assume that the estimated model is the true model..$^{10}$

As suggested in Heckman et al (1998), the sample is pared slightly to create a more comparable set of loans with and without local participation. Inspection of the sample indicates that loans with local participation are slightly larger, slightly longer in maturity, and have larger syndicates on average. Some of the average difference is created by very large loans, very long maturity loans, and very large syndicates. In order to create more homogeneous samples, very large loans (greater than $\$ 500 \mathrm{M}$ ), very long loans (longer than 8 years), and loans with large syndicates (more than 35 members) are excluded. These restrictions exclude 44 observations. reducing the sample to 1,099 observations. The remaining credit risk variables are indicator variables, so these restrictions ensure that the samples are comparable al ong the dimension of observable variables.

\footnotetext{
${ }^{9}$ W hile foreign capital is often less constrained than local bank capital, in practice foreign banks place limits on the exposure that their loan desks can take. Risk management practices typically result in country and borrower specific limits that serve as a ceiling on the total exposure to a particular country or borrower. These limits are allocated by product, often resulting in loan specific country and borrower limits. Moreover, the number of potential foreign participants is limited, so large loans can put a strain on foreign bank capacity.

10 Likelihood ratio statistics, which do not make such a strong assumption about the model, produce similar results.
} 


\subsection{Determinants of Local Lender Participation}

The first two columns of Table 5 present estimates for the model of local participation. The first column reports the coefficient estimates, and the second column reports the estimated probability impact computed at the sample average probability of local participation.

The two variables used as instruments for local bank participation have the expected sign and are statistically significant. The number of local banks active in loan syndications is positively related to the likelihood that a local bank participates in a loan. For example, increasing the number of local banks from 7 (as in Chile) to 13 (as in Columbia) increases the probability of local participation by 6.4 percentage points. $W$ ith the unconditional likelihood of local participation in Latin America only 27 percent, this represents nearly a 25 percent increase in the frequency of local lender participation. Similarly, the level of local liquidity, measured by LOCALLIQ, is significantly positively related to local participation. For example, increasing the level of local liquidity from .21 (Poland in 1997) to .31 (Poland in 2001 ) increases the probability of local participation by 3.1 percentage points. This represents nearly a 15 percent increase in the frequency of local participation in Poland.

The remaining coefficients indicate a local bank preference for riskier loans, as identified by the independent variables. Local lenders significantly prefer local firms (LOCALFIRM is positive), non-financial firms (FINANCIAL is negative), and unrated firms (UNRATED is positive). These variables likely indicate riskier borrowers who are more opaque to foreign lenders. In the sample, such borrowers have higher average loan spreads, consistent with them being more risky. While not shown in the table, the country credit risk measures suggest that local banks participate more often in riskier countries, with IICREDIT generally positive and IICREDITSQ generally negative, although statistical significance varies across years.

Finally, local lenders are significantly more likely to participate in loans that have larger syndicates. Increasing the syndicate size from less than four members to at least seven members increase the probability of local participation by 50 percentage points, a very large increase. Given the syndication process discussed above, this result is not surprising. Larger syndicates require the arrangers to broaden their search, increasing the likelihood that a local bank will be targeted. Results are qualitatively robust to segmenting the sample into loans with at least seven lenders and loans with strictly less than seven members. ${ }^{11}$

\footnotetext{
11 The data indicates that participation increases rather quickly as syndicate size moves above three members. However, further segmenting the sample drastically reduces sample sizes. Above six lender, the participation frequency remains relatively constant.
} 


\subsection{Determinants of Loan Spreads}

The last three columns of Table 5 present results for the model of loan spreads. The third and fourth columns report coefficient estimates for loans with no local bank participation and loans with local bank participation, respectively. The fifth column reports the difference between the coefficient estimates.

In unreported OLS regressions, adjusted R-squareds indicate that the models do a rather good job in explaining loan spreads, with the variables explaining roughly 50 percent of the variation in the data. Much of the explanatory power comes from the IICREDIT and IICREDITSQ variables, which vary by year and provide 16 additional variables not shown in the table. The estimated coefficient on IICREDIT is negative in every year and significantly different from zero at the 1 percent level in all cases. Borrowers from higher ranked countries receive lower spreads. IICREDITSQ is positive in every year and significantly different from zero at the 5 percent level in six of the eight years, suggesting a non-linear relationship between the Institutional Investor rating and spreads. Estimated coefficients do tend to vary over time, and the data easily rejects the hypothesis that IICREDIT and IICREDITSQ are constant over time. In general, the coefficients suggest that a higher ranking provides more benefit during periods of global macroeconomic stress, such as in 1999 and 2001 when average loan spreads were very high.

The coefficients on other control variables tend to have the expected pattern. Financial firms (FINANCIAL), firms with public ownership (PUBLIC), and firms with a foreign parent (the complement of LOCALFIRM) receive significantly lower spreads, but only when there is no local bank participation. Given the result that local banks are less likely to participate in loans to such borrowers, the results suggest that local bank participation is most valuable where spreads would otherwise be higher: non-financial firms, purely privately owned firms, and firms domestically owned. Compared to the complement borrower types, these firms are likely to be more opaque, subject to higher agency costs, and generally riskier. However, with a local bank participating in the syndicate, these firms receive prices similar to other firms.

The type of Ioan matters for pricing, with revolving credit lines (TYPE_REV) receiving lower spreads. This result replicates the finding in Carey and Nini (2004) for a larger sample of loans to borrowers from developed countries. Similarly, the purpose of the loan matters, as loans funding significant growth (PURP_CHGCTRL) or changes in capital structure (PURP_CAPSTR) carry spreads higher than loans funding working capital used for unspecified purposes. The impact of these variables does not vary with the participation of a local lender.

The maturity variables (M AT1836, M AT3660, M AT60p) suggest that loans with maturity longer than 18 months receive slightly lower spreads, and the effect appears slightly stronger for loans without local participation. The loan size variables (SIZE50100, SIZE100150, SIZE150250, SIZE250P) indicate that larger loans receive slightly lower spreads, and the 
effect does not vary based on local participation. Secured loans (SECURED) carry larger spreads, likely reflecting unobserved risk related to the borrower that is correlated with the use of collateral in the loan. Finally, the number of banks in the syndicate (NBANK46, NBANK 713, NBA NK14P) does not appear related to loan spreads.

Finally, the estimated covariance between error terms indicates a significantly negative correlation between the error term in the local bank participation equation and the error term in the spread equation without local participation. This implies that when the participation error is unexpectedly high, making it less likely that a local bank will participate in the loan, the loan spread tends to be unexpectedly low. This likely reflects the exclusion of certain borrower specific risk traits that have an effect similar to the variables FINANCIAL, PUBLIC, and LOCALFIRM. These variables all suggest that loans carrying lower spreads are less likely to have a local lender, likely because arranging banks can more easily find foreign banks for such loans, since they likely require less monitoring.

\subsection{The Impact of Local Participation on Loan Spreads}

The coefficient estimates reported in Table 5 are used to construct the counterfactual Ioan spreads derived in (3). For loans with local participation, comparing the counterfactual with the actual Ioan spread yields an estimate of the difference in spreads that would have resulted had no local lender participated in the loan. For the 304 loans with local participation, the sample mean (median) impact is - 29 (-29) basis points, meaning that the average loan with local participation had an economically significantly lower spread than an otherwise similar loan without local participation. The standard error of the mean estimate is 11.7 basis points, so the average impact is statistically different from zero at conventional significance levels. The $25^{\text {th }}$ percentile of the distribution $-98 \mathrm{bps}$, but the $75^{\text {th }}$ percentile is $+84 \mathrm{bps}$. Several sources of variation in the estimated impact are addressed in Table 6.

Panel A presents the impact of local bank participation by the borrower's country. The median estimate is similar in Latin America and Eastern Europe but shows significant variation by country. In 10 of the 13 countries, the median impact is negative, confirming the extensive effect of local bank participation. However, the impact appears larger in some countries, Venezuela and Croatia for example, than in other countries, such as Chile, Colombia, and Russia, where the effect is positive.

Panel B presents the results by year of the loan. A gain, the median impact is negative in most years but displays substantial variation. The variation is, in part, due to sampling variation created by the small sample size in any particular year. However, the estimates also suggest a pattern that reflects the underlying costs and benefits of locally provided finance. In years of macroeconomic crisis, Latin America and 2002 and Eastern Europe in 1999, the impact of local bank participation is relatively large. During these episodes, local banking capacity (confirmed by measure of banking liquidity relative to GDP) was relatively scarce, 
making the inclusion of a local bank relatively costly. However, the benefit conveyed to the borrower is relatively large, as reflected by the large spread impact.

Panel $C$ shows the local participation impact across various categories of borrowers and time periods. Most noticeably, local firms, non-financial firms, and private firms receive a larger benefit than the average loan, with the mean and median impact in these groups more negative than average. Such firms are generally considered to be more opaque and likely to be plagued by larger agency and information costs. W ithout local participation, Table 5 indicates significantly higher spreads for such firms, reflecting their larger credit risk. Finally, the bottom two rows of Table 6 show the estimated impact during times when country credit risk is relatively high and times when country-level banking liquidity is relatively high. The splits are formed by country by taking observations above and below the median values of LOCALLIQ and IICREDIT, so each country contributes observations to each portion of the sample. During periods of high LOCALLIQ, the impact of local participation is slightly smaller than periods of Iow LOCALLIQ, reflecting the smaller cost of including a local bank and the equilibrium result that more local banks are included in syndicates. However, during periods of high IICREDIT, the impact is even larger than average, indicating that local participation is most valuable when country credit risk is high. It is during these times when monitoring services are most valuable.

\section{Conclusions}

Variation in the inclusion of a local bank in syndicated loans to emerging market borrowers confirms two important results regarding the benefit of financial intermediation. First, local banks appear to reduce borrowing costs that would otherwise be charged by a syndicate composed of all foreign lenders. Second, the benefit conveyed by local lenders is largest for riskier borrowers, resulting in foreign arranging banks strategically using local banks for such loans.

The reduction in loan spreads is economically quite large, roughly 10 percent of the average spread. The size of the benefit suggests that local banks provide a positive externality that permits other lenders to increase their supply of funds at a given spread, or equivalently, reduce their required spread for a given amount of funding. The externality likely reflects a reduction in information or agency costs that benefits all syndicate members, a conjecture supported empirically by identifying cases where the benefit is largest: local, non-financial, and non-public firms borrowing during periods of high country risk.

The data confirms the industry's perception that syndicate members are strategically chosen to maximize the likelihood of successful syndication. Here, all-foreign-lender syndicates tend to have lower spreads, suggesting that foreign banks are attracted to firms with lower credit risk. This is consistent with industry practice of finding willing foreign banks first before moving on to local banks. 
Finally, those concerned that foreign banks 'cherry pick' the best borrowers and leave local banks with 'lemons' must account for the likely advantage that local banks have in serving riskier borrowers. The data used here do confirm an unconditional positive correlation between local banks and loan spreads, reflecting that local banks are more often included in syndicates for riskier borrowers. However, local banks appear to have a beneficial influence on realized spreads by lowering them from what they would be otherwise. The aggregate result is a lower cost of capital for local borrowers, which is an unambiguous positive for the country. Any increased risk concentrated in local banks should be handled through bank capital and/or prudential regulation rather than through restrictions on the borrower-lender matching process. 


\section{References}

Altunbas, Yener and Blaise Gadanecz (2003). "Developing country economic structure and the pricing of syndicated credits, Journal of Development Studies, forthcoming.

Beck, Thorston, Asli Demirguc-Kunt, and Vojislav Maksimovic (2004). "Financial and Legal Constraints to Growth: Does Firm Size M atter," Journal of Finance, forthcoming.

Berger, Allen N., Leora F. Klapper, and Gregory F. Udell (2001). "The ability of banks to lend to informationally opaque small businesses," Journal of Banking and Finance (25), 21272167.

Best, Ronald and H ang Zhang (1993). "A Iternative Information Sources and the Information Content of Bank Loans," Journal of Finance (48), 1507-1522.

Carey, Mark and Greg Nini (2004). "Is the Corporate Loan M arket Globally Integrated? A Pricing Puzzle," working paper.

Demirguc-Kunt, Asli and Vojislav Maksimovic (1999). "Institutions, financial markets, and firm debt maturity," Journal of Financial Economics (54), 295-336.

Dennis, Steven and Donald Mullineaux (2000). "Syndicated Loans," Journal of Financial Intermediation (9), 404-426.

Diamond, Douglas (1984). "Financial Intermediation and Delegated M onitoring," Review of Economic Studies (51:3), 393-414.

Eichengreen, Barry and Ashoka Moody (2003). "Lending Booms, Reserves and the Sustainability of Short-Term Debt: Inferences from the Pricing of Syndicated Bank Loans," Journal of Development Economics (63:1), 5-44.

Esty, Benjamin C. and W illiam L. Megginson (2003), "Creditor Rights, Enforcement, and Debt Ownership Structure: Evidence from the Global Syndicated Loan M arket," Journal of Financial and Quantitative A nalysis,forthcoming.

Esty, Benjamin C. (2003), "W hen Do Foreign Banks Finance Domestic Investment? New Evidence on the Importantce of Legal and Financial Systems," working paper.

Goldberg, Linda and Anthouny Saunders (1981). "The Determinants of Foreign Banking A ctivity in the United States," Jounrnal of M oney, Credit, and Banking (12), 17-32. 
Hadlock, Charles and Christopher James (2002). "Do Banks Provide Financial Slack" Journal of Finance (57:3), 1383-1419.

Heckman, James, Hidehiko Ichimura, Jeffrey Smith, and Petra Todd (1998). "Characterizing Selection Bias Using Experimental Data," Econometrica (66), 1017-1098.

International M onetary Fund. "Global Financial Stability Report", various years.

Karolyi, G. Andrew and Rene M. Stulz (2002), "Are Financial Assets Priced Locally or Globally?" prepared for $\mathrm{Handbook}$ of the Economics of Finance (George Constantinides, Milton Harris, and Rene M. Stulz eds), North-Holland.

La Porta, R., F. Lopez de-Silanes, A. Shliefer, and R. Vishny (1998). "Law and Finance," Journal of Political Economy (106), 1113-1155.

Levine, Ross (1999). "Law, finance, and economic growth," Journal of Financial Intermediation (8:1-2), 8-35.

Levine, Ross, Norman Loayza and Thorsten Beck (2000). "Financial intermediation and growth: causality and causes," Journal of M onetary Economics (46:1), 31-77.

Maddala, G. S. and F.D. Nelson (1975). "Switching Regression Models with Exogenous and Endogenous Switching" in "Proceedings of the Business and Economic Statistics Section, American Statistical A ssociation," 423-426.

Miller, Darius and John Puthenpurackal (2002). "The Costs, Determinants, and W ealth Effects of International Capital Raising: Evidence from Public Yankee Bonds," Journal of Financial Intermediation (11:4), 455-485.

Rajan, Raghuram and Luigi Zingales (1998). "Financial Dependence and Growth," American Economic Review (88), 559-587.

Slovin, Myron, M arie Shuska, and John Polonchek (1993). "The Value of Bank Durability: Borrowers as the Bank Stakeholders," Journal of Finance (48), 1507-1522. 
Table 1. Gross Private M arket Financing to Emerging Markets

Numbers in bold are the total amount of private financing to emerging market countries within a particular region, measured in billions of U.S. dollars. The share amounts are the dollar shares of each instrument reported in percentage points. The source of all the data is IM F, Global Financial Stability Report (2003).

\begin{tabular}{lrrrrrrrr}
\hline Region & 1995 & 1996 & 1997 & 1998 & 1999 & 2000 & 2001 & 2002 \\
\hline Eastern Europe & $\mathbf{1 7 . 3}$ & $\mathbf{2 1 . 6}$ & $\mathbf{3 8 . 9}$ & $\mathbf{3 5 . 6}$ & $\mathbf{2 6 . 2}$ & $\mathbf{3 7 . 0}$ & $\mathbf{2 2 . 8}$ & $\mathbf{3 0 . 3}$ \\
Bond Share & 38 & 35 & 42 & 67 & 53 & 38 & 51 & 49 \\
Equity Share & 3 & 6 & 8 & 7 & 5 & 9 & 1 & 5 \\
Loan Share & 58 & 59 & 50 & 26 & 42 & 53 & 48 & 45 \\
Latin America & $\mathbf{3 5 . 9}$ & $\mathbf{6 3 . 0}$ & $\mathbf{8 9 . 2}$ & $\mathbf{6 5 . 7}$ & $\mathbf{6 1 . 4}$ & $\mathbf{6 9 . 1}$ & $\mathbf{5 2 . 7}$ & $\mathbf{3 1 . 4}$ \\
Bond Share & 65 & 74 & 58 & 60 & 62 & 52 & 64 & 58 \\
Equity Share & 2 & 6 & 6 & 0 & 1 & 7 & 0 & 0 \\
Loan Share & 34 & 20 & 36 & 40 & 36 & 41 & 36 & 42 \\
\hline
\end{tabular}




\section{Table 2. Market Shares and Portfolio Allocations by Lender Region}

Market shares are based on actual loan allocation amounts in 2002 only. The borrower's country is based on the location of the borrowing entity, while the lender's region is based on the location of the lenders parent. The $\mathrm{W}$ orld Share row reports the market share of lenders in the global syndicated loan market for 2002. All data is taken from the Loanware sample described in Section 4.1.

\begin{tabular}{lcccccc}
\hline \multirow{2}{*}{$\begin{array}{l}\text { Borrower } \\
\text { Country }\end{array}$} & $\begin{array}{c}\text { North } \\
\text { America }\end{array}$ & $\begin{array}{c}\text { Western } \\
\text { Europe }\end{array}$ & Japan & $\begin{array}{c}\text { Latin } \\
\text { America }\end{array}$ & $\begin{array}{c}\text { Eastern } \\
\text { Europe }\end{array}$ & Other \\
\hline Latin America & $\mathbf{3 4}$ & $\mathbf{5 1}$ & $\mathbf{7}$ & $\mathbf{6}$ & $\mathbf{0}$ & $\mathbf{3}$ \\
Argentina & 33 & 54 & 3 & 5 & 0 & 5 \\
Brazil & 33 & 44 & 11 & 8 & 0 & 3 \\
Mexico & 36 & 50 & 6 & 5 & 0 & 2 \\
Other & 32 & 56 & 5 & 5 & 0 & 3 \\
Eastern Europe & $\mathbf{8}$ & $\mathbf{7 2}$ & $\mathbf{7}$ & $\mathbf{0}$ & $\mathbf{6}$ & $\mathbf{7}$ \\
Poland & 9 & 68 & 8 & 0 & 9 & 5 \\
Russia & 4 & 77 & 7 & 0 & 4 & 8 \\
Other & 10 & 71 & 5 & 0 & 6 & 8 \\
World Share & 46 & 41 & 8 & 0 & 0 & 4 \\
\hline
\end{tabular}




\section{Table 3. Syndicate Composition}

The borrower's country is based on the location of the borrowing entity. Loan Tranches is the total number of observations. Number of banks reports the aggregate number of unique banks participating in loans to borrowers from each country. Local banks are based in the borrowers country and not subsidiaries of foreign institutions. Number of Banks reports the total number of unique local and non-local lenders that have participated in at least one sample loan. Incidence Frequency the aggregate frequency, by loan count, with which local and non-local banks participated in sample loans. Condition Allocation reports the average percentage of a loan provided conditional on a local bank in the syndication. The source of the data is Loanware over the entire sample period 1995-2002, as described in Section 4.1.

\begin{tabular}{|c|c|c|c|c|c|c|c|}
\hline \multirow{2}{*}{$\begin{array}{l}\text { Borrower } \\
\text { Country } \\
\end{array}$} & \multirow{2}{*}{$\begin{array}{c}\text { Loan } \\
\text { Tranches } \\
\end{array}$} & \multicolumn{2}{|c|}{ Number of Banks } & \multicolumn{2}{|c|}{ Incidence Frequency } & \multicolumn{2}{|c|}{ Conditional Allocation } \\
\hline & & Local & Other & Local & Other & Local & Other \\
\hline Latin America & 786 & 65 & 88 & 27 & 100 & 16 & 84 \\
\hline Argentina & 142 & 10 & 21 & 30 & 100 & 15 & 85 \\
\hline Brazil & 153 & 15 & 27 & 48 & 100 & 16 & 84 \\
\hline Chile & 151 & 7 & 14 & 9 & 100 & 19 & 81 \\
\hline Colombia & 65 & 13 & 14 & 25 & 100 & 24 & 76 \\
\hline Mexico & 216 & 7 & 12 & 21 & 100 & 12 & 88 \\
\hline Peru & 21 & 4 & 8 & 43 & 100 & 22 & 78 \\
\hline Venezuela & 38 & 7 & 10 & 37 & 100 & 16 & 84 \\
\hline Eastern Europe & 357 & 40 & 69 & 28 & 100 & 13 & 87 \\
\hline Czech Republic & 46 & 2 & 19 & 9 & 100 & 9 & 91 \\
\hline Croatia & 34 & 3 & 6 & 35 & 100 & 6 & 94 \\
\hline Hungary & 67 & 5 & 20 & 24 & 100 & 8 & 92 \\
\hline Poland & 38 & 10 & 20 & 26 & 100 & 29 & 71 \\
\hline Romania & 27 & 12 & 22 & 67 & 100 & 14 & 86 \\
\hline Russia & 145 & 8 & 21 & 28 & 100 & 10 & 90 \\
\hline
\end{tabular}




\section{Table 4. Univariate Comparison of Loans W ith and W ithout Local Participation}

In panel $A$, the borrower's country is based on the location of the borrowing entity. In panel $B$, the loan year is based on the signing date of the loan. Loan Tranches is the total number of observations. Remaining values are sample means for four loan characteristics conditioned on the presence of a local participant. Size is the total amount of funds borrowed, measured in millions of nominal U.S. dollars. Spread is the interest rate spread charged on the loan, including all fees paid, measured in basis points. M aturity is the total tenor of the loan, measured in months. Percent secured is the percentage, by count, of the loans that have a specific pledge of collateral. Loans with a local participant have at least one syndicate member that is domiciled in the same country as the borrower but does not have a foreign parent.

\begin{tabular}{|c|c|c|c|c|c|c|c|c|c|}
\hline \multirow{3}{*}{$\begin{array}{l}\text { Borrower } \\
\text { Country }\end{array}$} & \multirow{3}{*}{$\begin{array}{c}\text { Loan } \\
\text { Tranches }\end{array}$} & \multicolumn{2}{|c|}{ Size (\$millions) } & \multicolumn{2}{|c|}{ Spread (bps) } & \multicolumn{2}{|c|}{ Maturity (months) } & \multicolumn{2}{|c|}{ Percent Secured } \\
\hline & & No Local & With Local & No Local & With Local & No Local & With Local & No Local & With Local \\
\hline & & Participant & Participant & Participant & Participant & Participant & Participant & Participant & Participant \\
\hline Total All Countries & 1143 & 145 & 128 & 213 & 296 & 40 & 38 & 24 & 30 \\
\hline Latin America & 786 & 156 & 150 & 206 & 301 & 42 & 40 & 23 & 25 \\
\hline Argentina & 142 & 119 & 121 & 283 & 343 & 33 & 35 & 24 & 10 \\
\hline Brazil & 153 & 156 & 207 & 248 & 298 & 32 & 32 & 43 & 43 \\
\hline Chile & 151 & 184 & 107 & 111 & 253 & 51 & 50 & 9 & 15 \\
\hline Columbia & 65 & 124 & 89 & 248 & 295 & 56 & 44 & 16 & 6 \\
\hline Mexico & 216 & 169 & 136 & 199 & 263 & 39 & 46 & 28 & 22 \\
\hline Peru & 21 & 65 & 95 & 250 & 340 & 54 & 60 & 0 & 11 \\
\hline Venezuela & 38 & 162 & 128 & 246 & 350 & 53 & 52 & 29 & 21 \\
\hline Eastern Europe & 357 & 120 & 81 & 227 & 285 & 36 & 32 & 25 & 41 \\
\hline Czech Republic & 46 & 159 & 132 & 68 & 57 & 49 & 60 & 12 & 0 \\
\hline Croatia & 34 & 69 & 51 & 122 & 134 & 35 & 53 & 9 & 0 \\
\hline Hungary & 67 & 74 & 76 & 52 & 108 & 53 & 60 & 8 & 13 \\
\hline Poland & 38 & 90 & 135 & 61 & 107 & 39 & 50 & 4 & 20 \\
\hline Romania & 27 & 87 & 81 & 209 & 301 & 29 & 20 & 11 & 50 \\
\hline Russia & 145 & 148 & 74 & 445 & 456 & 23 & 15 & 49 & 68 \\
\hline
\end{tabular}


Table 4 (continued). Univariate Comparison of Loans W ith and W ithout Local Participation

B. By Loan Y ear

\begin{tabular}{|c|c|c|c|c|c|c|c|c|c|}
\hline \multirow[b]{2}{*}{ Loan Year } & \multirow[b]{2}{*}{$\begin{array}{c}\text { Loan } \\
\text { Tranches }\end{array}$} & \multicolumn{2}{|c|}{ Size (\$millions) } & \multicolumn{2}{|c|}{ Spread (bps) } & \multicolumn{2}{|c|}{ Maturity (months) } & \multicolumn{2}{|c|}{ Percent Secured } \\
\hline & & $\begin{array}{c}\text { No Local } \\
\text { Participant }\end{array}$ & $\begin{array}{l}\text { With Local } \\
\text { Participant }\end{array}$ & $\begin{array}{c}\text { No Local } \\
\text { Participant }\end{array}$ & $\begin{array}{l}\text { With Local } \\
\text { Participant }\end{array}$ & $\begin{array}{c}\text { No Local } \\
\text { Participant }\end{array}$ & $\begin{array}{l}\text { With Local } \\
\text { Participant }\end{array}$ & $\begin{array}{c}\text { No Local } \\
\text { Participant }\end{array}$ & $\begin{array}{l}\text { With Local } \\
\text { Participant }\end{array}$ \\
\hline Latin America & 786 & 156 & 150 & 206 & 301 & 42 & 40 & 23 & 25 \\
\hline 1995 & 33 & 126 & 124 & 215 & 513 & 46 & 32 & 33 & 0 \\
\hline 1996 & 64 & 131 & 139 & 160 & 236 & 51 & 37 & 11 & 0 \\
\hline 1997 & 126 & 171 & 168 & 149 & 210 & 49 & 48 & 26 & 24 \\
\hline 1998 & 130 & 167 & 237 & 201 & 248 & 38 & 32 & 30 & 15 \\
\hline 1999 & 97 & 175 & 150 & 331 & 522 & 35 & 37 & 28 & 14 \\
\hline 2000 & 122 & 147 & 128 & 211 & 318 & 40 & 40 & 21 & 41 \\
\hline 2001 & 124 & 148 & 125 & 171 & 293 & 42 & 39 & 16 & 38 \\
\hline 2002 & 90 & 152 & 126 & 236 & 297 & 42 & 43 & 23 & 20 \\
\hline Eastern Europe & 357 & 120 & 81 & 227 & 285 & 36 & 32 & 25 & 41 \\
\hline 1995 & 22 & 86 & 131 & 106 & 304 & 39 & 38 & 6 & 0 \\
\hline 1996 & 51 & 143 & 87 & 161 & 199 & 41 & 51 & 2 & 0 \\
\hline 1997 & 104 & 144 & 64 & 241 & 300 & 34 & 40 & 12 & 17 \\
\hline 1998 & 55 & 109 & 65 & 254 & 183 & 33 & 40 & 33 & 13 \\
\hline 1999 & 17 & 70 & 61 & 139 & 332 & 32 & 9 & 29 & 67 \\
\hline 2000 & 23 & 56 & 116 & 212 & 229 & 38 & 25 & 46 & 50 \\
\hline 2001 & 25 & 62 & 75 & 306 & 340 & 35 & 24 & 55 & 79 \\
\hline 2002 & 60 & 124 & 88 & 314 & 346 & 37 & 23 & 62 & 74 \\
\hline
\end{tabular}




\section{Table 5. Determinants of Local Participation and Conditional Loan Spreads}

The table reports maximum likelihood estimates of the empirical model presented in Section 4. Results for the local participation equation are reported in the first two columns. The first column reports coefficient estimates and asymptotic standard errors, in parentheses. The Probability column reports the change in probability of local participation due to a change in the independent variable, computed at the sample average probability of local participation. All variables except NUMBNK and LOCALLIQ are dummy variables, so the change is conditional on a change from 0 to 1 . For NUM BNK and LOCA LLIQ, the change is based on a move from the $25^{\text {th }}$ percentile to the $75^{\text {th }}$ percentile. The spread equations are reported in the final three columns. The dependent variable is the log of the loan spread and the coefficients are permitted to vary conditional on the presence of a local lender. The difference column reports the difference between coefficients. Throughout the table, ** (*) denotes values significantly different from zero at the 1 (5) percent level based on a $W$ ald test using the estimated asymptotic standard errors. 
Table 5 (continued). Determinants of Local Participation and Conditional Loan Spreads

\begin{tabular}{|c|c|c|c|c|c|}
\hline & \multicolumn{2}{|c|}{ Local Participation Equation } & \multicolumn{3}{|c|}{ Log Loan Spread Equation } \\
\hline & Coefficient & Probability & No Local & With Local & Difference \\
\hline INTERCEPT & $\begin{array}{c}-2.139 * \\
(0.911)\end{array}$ & & $\begin{array}{c}8.283 \\
(0.350)\end{array}$ & $\begin{array}{c}7.276 \text { ** } \\
(0.896)\end{array}$ & $\begin{array}{r}1.008 \\
(0.962)\end{array}$ \\
\hline NUMBNK & $\begin{array}{c}0.263 * \\
(0.117)\end{array}$ & $6.4 \%$ & & & \\
\hline LOCALLIQ & $\begin{array}{c}0.368 * \\
(0.158)\end{array}$ & $3.1 \%$ & & & \\
\hline UNRATED & $\begin{array}{c}0.262 * \\
(0.109)\end{array}$ & $9.4 \%$ & $\begin{array}{r}-0.022 \\
(0.057)\end{array}$ & $\begin{array}{r}-0.073 \\
(0.077)\end{array}$ & $\begin{array}{r}0.051 \\
(0.096)\end{array}$ \\
\hline FINANCIAL & $\begin{array}{l}-0.359 \text { * } \\
(0.151)\end{array}$ & $-10.6 \%$ & $\begin{array}{l}-0.463 * * \\
(0.078)\end{array}$ & $\begin{array}{r}0.066 \\
(0.131)\end{array}$ & $\begin{array}{l}-0.529 \text { ** } \\
(0.153)\end{array}$ \\
\hline PUBLIC & $\begin{array}{r}-0.077 \\
(0.125)\end{array}$ & $-2.5 \%$ & $\begin{array}{l}-0.307 * * \\
(0.061)\end{array}$ & $\begin{array}{r}-0.109 \\
(0.085)\end{array}$ & $\begin{array}{l}-0.198 * \\
(0.104)\end{array}$ \\
\hline LOCALFIRM & $\begin{array}{l}0.427 * * \\
(0.142)\end{array}$ & $15.7 \%$ & $\begin{array}{l}0.239 \text { ** } \\
(0.065)\end{array}$ & $\begin{array}{r}-0.053 \\
(0.125)\end{array}$ & $\begin{array}{c}0.292 * \\
(0.141)\end{array}$ \\
\hline TYPE_REV & $\begin{array}{r}-0.034 \\
(0.117)\end{array}$ & $-1.1 \%$ & $\begin{array}{l}-0.228 * * \\
(0.055)\end{array}$ & $\begin{array}{r}-0.143 \\
(0.076)\end{array}$ & $\begin{array}{r}-0.085 \\
(0.094)\end{array}$ \\
\hline PURP_CHGCTRL & $\begin{array}{r}0.233 \\
(0.181)\end{array}$ & $8.3 \%$ & $\begin{array}{l}0.521 \text { ** } \\
(0.090)\end{array}$ & $\begin{array}{l}0.496 * * \\
(0.123)\end{array}$ & $\begin{array}{r}0.025 \\
(0.152)\end{array}$ \\
\hline PURP_CAPSTR & $\begin{array}{r}0.126 \\
(0.111)\end{array}$ & $4.4 \%$ & $\begin{array}{l}0.191 \text { ** } \\
(0.055)\end{array}$ & $\begin{array}{c}0.174 * \\
(0.075)\end{array}$ & $\begin{array}{r}0.017 \\
(0.093)\end{array}$ \\
\hline MAT1836 & $\begin{array}{r}0.200 \\
(0.130)\end{array}$ & $7.1 \%$ & $\begin{array}{l}-0.174 * \\
(0.068)\end{array}$ & $\begin{array}{l}-0.055 \\
(0.090)\end{array}$ & $\begin{array}{r}-0.119 \\
(0.113)\end{array}$ \\
\hline MAT3660 & $\begin{array}{l}-0.029 \\
(0.132)\end{array}$ & $-0.9 \%$ & $\begin{array}{l}-0.145 * \\
(0.064)\end{array}$ & $\begin{array}{l}-0.064 \\
(0.085)\end{array}$ & $\begin{array}{r}-0.080 \\
(0.106)\end{array}$ \\
\hline MAT60P & $\begin{array}{r}-0.041 \\
(0.207)\end{array}$ & $-1.4 \%$ & $\begin{array}{r}-0.060 \\
(0.093)\end{array}$ & $\begin{array}{r}-0.013 \\
(0.140)\end{array}$ & $\begin{array}{r}-0.048 \\
(0.168)\end{array}$ \\
\hline SIZE50100 & $\begin{array}{r}-0.114 \\
(0.124)\end{array}$ & $-3.7 \%$ & $\begin{array}{l}-0.157 * * \\
(0.060)\end{array}$ & $\begin{array}{r}-0.029 \\
(0.078)\end{array}$ & $\begin{array}{r}-0.127 \\
(0.099)\end{array}$ \\
\hline SIZE100150 & $\begin{array}{r}-0.094 \\
(0.150)\end{array}$ & $-3.1 \%$ & $\begin{array}{r}-0.077 \\
(0.076)\end{array}$ & $\begin{array}{l}-0.234 * \\
(0.091)\end{array}$ & $\begin{array}{r}0.157 \\
(0.119)\end{array}$ \\
\hline SIZE150250 & $\begin{array}{r}-0.191 \\
(0.158)\end{array}$ & $-6.0 \%$ & $\begin{array}{r}-0.031 \\
(0.083)\end{array}$ & $\begin{array}{l}-0.106 \\
(0.098)\end{array}$ & $\begin{array}{r}0.074 \\
(0.128)\end{array}$ \\
\hline SIZE250P & $\begin{array}{l}-0.482 * \\
(0.196)\end{array}$ & $-13.5 \%$ & $\begin{array}{r}-0.170 \\
(0.101)\end{array}$ & $\begin{array}{r}-0.011 \\
(0.144)\end{array}$ & $\begin{array}{r}-0.160 \\
(0.176)\end{array}$ \\
\hline SECURED & $\begin{array}{l}-0.072 \\
(0.112)\end{array}$ & $-2.4 \%$ & $\begin{array}{c}0.128 * \\
(0.057)\end{array}$ & $\begin{array}{r}0.121 \\
(0.072)\end{array}$ & $\begin{array}{r}0.007 \\
(0.092)\end{array}$ \\
\hline NBANK46 & $\begin{array}{l}0.766 \text { ** } \\
(0.174)\end{array}$ & $29.2 \%$ & $\begin{array}{r}0.011 \\
(0.087)\end{array}$ & $\begin{array}{l}-0.174 \\
(0.224)\end{array}$ & $\begin{array}{r}0.185 \\
(0.240)\end{array}$ \\
\hline NBANK713 & $\begin{array}{l}1.359 \text { ** } \\
(0.168)\end{array}$ & $50.2 \%$ & $\begin{array}{l}-0.001 \\
(0.120)\end{array}$ & $\begin{array}{r}-0.180 \\
(0.307)\end{array}$ & $\begin{array}{r}0.179 \\
(0.330)\end{array}$ \\
\hline NBANK14P & $\begin{array}{l}1.342 \text { ** } \\
(0.195)\end{array}$ & $49.6 \%$ & $\begin{array}{r}-0.019 \\
(0.127)\end{array}$ & $\begin{array}{r}-0.311 \\
(0.313)\end{array}$ & $\begin{array}{r}0.292 \\
(0.338)\end{array}$ \\
\hline Error Term Covariance & & & $\begin{array}{l}-0.213 * \\
(0.107)\end{array}$ & $\begin{array}{r}-0.023 \\
(0.281)\end{array}$ & \\
\hline INDUSTRY DUMMIES & & & & & \\
\hline IICREDIT * YR DUMMIES & & & & & \\
\hline IICREDITSQ * YR DUMMIES & & & & & \\
\hline Number of Observations & 1099 & & 795 & 304 & \\
\hline
\end{tabular}




\section{Table 6. Sample Statistics for Impact of Local Bank Participation}

The model results from Table 5 are used to infer the effect that local bank participation has on loan spreads. For each sample loan, counterfactual loan spreads are derived using (3), and the impact of local participation is given by the difference between the actual spread and the counterfactual. (Negative numbers mean that the spread is lower with local participation than the counterfactual without local participation.) The table reports the sample mean, median, and quartile values across the sample loans that have local participation. The "Basis Point I mpact" is the impact measured in basis points, and the "Percentage Impact" is the basis point impact divided by the sample mean spread. Panel A reports the results by borrower country; Panel $B$ by loan year; Panel $C$ reports the impact across various categories of loans.

\begin{tabular}{|c|c|c|c|c|c|c|}
\hline \multirow{2}{*}{$\begin{array}{l}\text { Borrower } \\
\text { Country } \\
\end{array}$} & \multicolumn{4}{|c|}{ Basis Point Impact } & \multicolumn{2}{|c|}{ Percentage Impact } \\
\hline & Mean & 25th Pctl & Median & 75th Pctl & Mean & Median \\
\hline Total All Countries & -29 & -98 & -29 & 84 & -10 & -10 \\
\hline Latin America & -20 & -95 & -29 & 114 & -7 & -10 \\
\hline Argentina & -95 & -96 & -35 & 133 & -28 & -10 \\
\hline Brazil & -7 & -111 & -23 & 114 & -2 & -8 \\
\hline Chile & 59 & -31 & 74 & 114 & 23 & 29 \\
\hline Colombia & 3 & -144 & 43 & 121 & 1 & 15 \\
\hline Mexico & 27 & -52 & -6 & 117 & 10 & -2 \\
\hline Peru & -25 & -69 & -28 & 56 & -7 & -8 \\
\hline Venezuela & -107 & -183 & -117 & -90 & -30 & -33 \\
\hline Eastern Europe & -48 & -103 & -28 & 40 & -16 & -10 \\
\hline Czech Republic & -42 & -56 & -48 & -29 & -73 & -83 \\
\hline Croatia & -177 & -260 & -191 & -89 & -132 & -143 \\
\hline Hungary & -55 & -88 & -49 & -21 & -57 & -51 \\
\hline Poland & -56 & -89 & -76 & -25 & -53 & -71 \\
\hline Romania & -47 & -130 & -17 & 97 & -16 & -6 \\
\hline Russia & -5 & -52 & 33 & 80 & -1 & 7 \\
\hline
\end{tabular}


Table 6 (continued). Sample Statistics for Impact of Local Bank Participation

B. By Loan Y ear

\begin{tabular}{lrrrrrrrr}
\hline & \multicolumn{9}{c}{ Basis Point Impact } & & \multicolumn{2}{c}{ Percentage Impact } \\
\cline { 2 - 4 } Loan Year & Mean & 25 th Pctl & Median & 75 th Pctl & & Mean & Median \\
\hline Latin America & -20 & -95 & -29 & 114 & & -7 & -10 \\
1995 & 226 & 10 & 264 & 404 & & 44 & 51 \\
1996 & -48 & -93 & -57 & -31 & & -20 & -24 \\
1997 & -26 & -93 & -32 & 21 & & -12 & -15 \\
1998 & -43 & -162 & -42 & 105 & & -19 & -18 \\
1999 & 83 & -122 & 79 & 219 & & 16 & 16 \\
2000 & 3 & -95 & -44 & 120 & & 1 & -14 \\
2001 & 51 & -48 & 100 & 152 & & 17 & 34 \\
2002 & -124 & -137 & -46 & 74 & & -42 & -16 \\
& & & & & & & \\
Eastern Europe & -48 & -103 & -28 & 40 & & -16 & -10 \\
1995 & 20 & 6 & 10 & 81 & & 7 & 3 \\
1996 & -51 & -79 & -30 & -12 & & -26 & -15 \\
1997 & -55 & -191 & -5 & 57 & & -18 & -2 \\
1998 & -71 & -145 & -56 & -25 & & -37 & -29 \\
1999 & -230 & -613 & -217 & 138 & & -69 & -65 \\
2000 & -128 & -151 & -77 & -30 & & -56 & -34 \\
2001 & 0 & -90 & 22 & 79 & & 0 & 6 \\
2002 & -11 & -54 & -12 & & 47 & & -3 & -3 \\
\hline
\end{tabular}

C. By Various Loan Characteristics

\begin{tabular}{lccccccc}
\hline & \multicolumn{3}{c}{ Basis Point Impact } & & \multicolumn{2}{c}{ Percentage Impact } \\
\cline { 2 - 4 } & Mean & 25 th Pctl & Median & 75 th Pctl & & Mean & Median \\
\hline Total All Loans & -29 & -98 & -29 & 84 & & -10 & -10 \\
Local Firms (LOCALFIRM=1) & -37 & -104 & -31 & 79 & & -13 & -10 \\
Non-Financial Firms (FINANCIAL=0) & -40 & -110 & -45 & 80 & & -14 & -15 \\
Private Firms (PUBLIC=0) & -43 & -107 & -39 & 71 & -14 & -13 \\
High LOCALLIQ & -5 & -107 & -20 & 97 & & -1 & -6 \\
High IICREDIT & -72 & -130 & -38 & 78 & -22 & -11 \\
\hline
\end{tabular}

